\title{
Margaret McCartney: The NHS needs a new era of political leadership
}

\author{
Margaret McCartney general practitioner
}

Glasgow

The chairs of the Health Committee, Public Accounts Committee, and Communities and Local Government Committee have written to the government calling for a "new political consensus" on UK health and social care. They note the "immense challenge" of ensuring adequate social care in the coming decades and think that this "can best be achieved if there is cross party consensus."

For a long time the prevailing political narrative has been that the holy grails of individual leadership, technology, and innovation will "save the NHS." In practice, this has led to money and morale being squandered on poorly evidenced interventions that are rarely subjected to fair tests and are often pushed through by party politics. We've built attractive ideas in the sky but failed to take care of the foundations of the NHS - the unending need for personal, hands-on care, as well as care for the staff providing it.

Ed Straw, a former adviser to the Labour Party and to Labour and Conservative ministers, uses the phrase "zigzag politics" to describe short term vote winners that lack the substance of long term effectiveness. ${ }^{1}$

A mix of party politics, think tank-ology, charity pressure groups, and a variety of industries knocking on open doors has led to policy making of dubious, even negative value. Examples range from private finance initiative contracts to dementia screening, from mandatory appraisal to a target based culture with many harms attached.

Is there another way? Why should we accept the NHS as just another round of a political career? The NHS isn't a one party stand but a marriage of population to philosophy.
The NHS was born from politics, and all of our main political parties-even UKIP—have pledged support for the NHS and its principle of being "free at the point of need." There should be little argument, therefore, about the aim of parliamentary politics: ensuring a sustainable service capable of meeting those needs.

The NHS isn't a one party stand but a marriage of population to philosophy

We need to aim higher and for longer. We need a cross party assembly of politicians charged with the stewardship of the NHS's next 100 years. We need politicians to interrogate experts, commission (and pay attention to) systematic reviews, insist on cost effectiveness, and ask for evidence at every turn.

The NHS is culturally valuable because it speaks to us about fairness, community, vocation, and safety. We need a new era of political leaders-ones who are willing to embody those attributes collectively and to work for the population, towards goals that extend beyond the lifetime of their political careers.

Competing interests: See www.bmj.com/about-bmj/freelancecontributors/margaret-mccartney.

Provenance and peer review: Commissioned; not externally peer reviewed.

Follow Margaret on Twitter, @mgtmccartney

Straw E. Stand and deliver: a design for successful government. Treaty for Government, 2014.

Published by the BMJ Publishing Group Limited. For permission to use (where not already granted under a licence) please go to http://group.bmj.com/group/rights-licensing/ permissions 